

\title{
Writing African History in France during the Colonial Era
}

Sophie Dulucq

\section{To cite this version:}

Sophie Dulucq. Writing African History in France during the Colonial Era. Thomas Spear. Oxford Research Encyclopedia of African History, 2018, 10.1093/acrefore/9780190277734.013.313 . halshs01939221

\section{HAL Id: halshs-01939221 https://shs.hal.science/halshs-01939221}

Submitted on 29 Nov 2018

HAL is a multi-disciplinary open access archive for the deposit and dissemination of scientific research documents, whether they are published or not. The documents may come from teaching and research institutions in France or abroad, or from public or private research centers.
L'archive ouverte pluridisciplinaire HAL, est destinée au dépôt et à la diffusion de documents scientifiques de niveau recherche, publiés ou non, émanant des établissements d'enseignement et de recherche français ou étrangers, des laboratoires publics ou privés. 


\section{Oxford Research Encyclopedia of African History}

\section{Writing African History in France during the Colonial Era}

Sophie Dulucq

Subject: Colonial Conquest and Rule, Historiography and Methods, Intellectual History

Online Publication Date: Oct 2018 DOI: 10.1093/acrefore/9780190277734.013.313

\section{Summary and Keywords}

In the second half of the 19th century, French imperial expansion in the south of the Sahara led to the control of numerous African territories. The colonial rule France imposed on a diverse range of cultural groups and political entities brought with it the development of equally diverse inquiry and research methodologies. A new form of scholarship, africanisme, emerged as administrators, the military, and amateur historians alike began to gather ethnographic, linguistic, judicial, and historical information from the colonies. Initially, this knowledge was based on expertise gained in the field and reflected the pragmatic concerns of government rather than clear, scholarly, interrogation in line with specific scientific disciplines.

Research was thus conducted in many directions, contributing to the emergence of the so-called colonial sciences. Studies by Europeans scholars, such as those carried out by Maurice Delafosse and Charles Monteil, focused on West Africa's past. In so doing, the colonial context of the late 19th century reshaped the earlier orientalist scholarship tradition born during the Renaissance, which had formerly produced quality research about Africa's past, for example, about medieval Sudanese states. This was achieved through the study of Arabic manuscripts and European travel narratives. In this respect, colonial scholarship appears to have perpetuated the orientalist legacy, but in fact, it transformed the themes, questions, and problems historians raised.

In the first instance, histoire coloniale (colonial history) focused the history of European conquests and the interactions between African societies and their colonizers. Between 1890 and 1920 a network of scientists, including former colonial administrators, struggled to institutionalize colonial history in metropolitan France. Academic positions were established at the Sorbonne and the Collège de France. Meanwhile, research institutions were created in French West Africa (Afrique Occidentale Française [AOF]), French Equatorial Africa (Afrique Équatoriale Française [AEF]), and Madagascar between 1900 and the 1930s. 
Yet, these imperial and colonial concerns similarly coincided with the rise of what was then known as histoire indigène (native history) centered on the precolonial histories of African societies. Through this lens emerged a more accurate vision of the African past, which fundamentally challenged the common preconception that the continent had no "history." This innovative knowledge was often co-produced by African scholars and intellectuals.

After the Second World War, interest in colonial history started to wane, both from an intellectual and a scientific point of view. In its place, the history of sub-Saharan Africa gained popularity and took root in French academic institutions. Chairs of African history were created at the Sorbonne in 1961 and 1964, held by Raymond Mauny and Hubert Deschamps, respectively, and in 1961 at the École Pratique des Hautes Études, fulfilled by Henri Brunschwig. African historians, who were typically trained in France, began to challenge the existing European scholarship. As a result, some of the methods and sources that had been born in the colonial era, were adopted for use by a new generation of historians, whose careers blossomed after the independences.

Keywords: France, colonialism, colonial sciences, colonial history, African studies, history of Africa, historiography

In his seminal study on the "invention" of African historiography in Europe during the 18th and 19th centuries, Pekka Masonnen wrote that "much of our knowledge of African past is based on secondary literature written during colonial times." ${ }^{1}$ This general statement is entirely valid as far as French African studies are concerned: French historical knowledge about Africa was indeed gradually accumulated in a colonial context, which has obviously damaged the appreciation of its scope, features, and potential achievements. Yet, as Fanny Colonna vigorously asserted in her essay about social science in colonial Algeria, "First of all, it is not possible to discard such literature, or even to do without it. It is also clear that, nowadays, it is hard to use it in a way that would not be both wild and guilty, in other words uncontrolled." ${ }^{2}$

It is therefore necessary to revisit the practice of African historical studies in late-19thand early-20th-century France to evaluate the context of their emergence, the characteristics and biases of their production, and the often underestimated weight of their legacy. In other words, when and how did a history of Africa emerge in colonial France, and by whom has this historical corpus gradually been established?

These questions may not seem complex at face value, but their answers are somewhat more challenging than might be expected. In the first instance, for example, it is not easy to identify a definitive corpus that clearly belongs to the discipline of history. Since the first encounters between Europeans and "natives" in the early modern era, explorers, travelers, scholars, missionaries, the military, and colonial agents, have written widely on African geography, inhabitants, traditions, and heritage (and even more so after the conquest of African sub-Saharan colonies in the 19th century). In fact, numerous documents (including those from unscholarly or administrative sources) often raised historic issues, such as the history of particular social groups or the origins of African 
"kingdoms." For decades, therefore, no clear line has been drawn between primary information gathered in the field, knowledge recycled by amateur practitioners, and historical analysis conducted by researchers and historians. Secondly, concepts such as "African studies" or "African history" did not exist before the second half of the 20th century. French historical insights into the history of Africa fell under the much broader banner of africanisme (a word whose meaning the translation "African studies" only partially manages to capture). French africanisme instead encompassed vastly interdisciplinary themes of disparate knowledge about Africa and African societies, composed without regard for the existing disciplines of history, ethnology, geography, zoology, linguistics, and so on. ${ }^{3}$ As such, the genealogy of African history can only be found among the complexities of heterogeneous sources, and must account for the shifting boundaries of different French academic disciplines between the 1880s and 1950s.

Let us instead visit a specific colonial library, whose dusty shelves are packed with documents, books, and articles written by half-forgotten authors, most of them French, and some of them African. ${ }^{4}$ The "history section" of this library will prove to be richer than one would have imagined in terms of the scientific accumulation of knowledge. As is to be expected, taking into account the French colonial context in which these historical texts were written or gathered, their content frequently reveals strong racial biases motivated by colonial agendas. But on closer reading, they nevertheless reveal interesting methodological innovations (regarding, for example, oral sources and the development of "native history," as it was called at the time), and the inclusion of several native African contributors.

\section{The Development of French Africanisme and of Colonial History in an Imperial Framework}

It is well documented that specific forms of knowledge have emerged in the context of European expansion throughout the world. For example, a knowledge often labeled as "imperial" or "colonial," led to the concepts of "imperial science" and "colonial science," which have been discussed, criticized, and sometimes abandoned. ${ }^{5}$ Although the development of proto-African studies in Europe dates back to the 16th century, it was in the 18th century that the collection of rare Arabic, Sudanese, and Ethiopian manuscripts became popular, owing to increased orientalist erudition. In Great Britain, for instance, William Desbourough Cooley's The Negroland of the Arabs Examined and Explained (1841) was considered a seminal text on precolonial knowledge of the Sudanese regions in the medieval period. ${ }^{6}$ Ultimately, scholarship on sub-Saharan Africa made dramatic progress in the context of 19th-century imperialism and colonial rule.

\section{Colonial History: Between Necessity and Curiosity}


In the French case more specifically, France's conquest of sub-Saharan territories during the second half of the 19th century prompted a considerable increase in studies devoted to African societies and political entities of the past. A network of amateur and professional scholars gradually formed, enabled and encouraged by French colonial authorities and institutions. As Pierre Singaravélou highlighted in a book devoted to "sciences coloniales" during the French Third Republic, the 1880s and 1890s "were a period of university reform and growth of the human sciences, expansion of commercial and applied sciences, and renewed imperial aggression; all three developments facilitated the institutionalization of new disciplines." 7

Colonial administrations were eager to collect information about the newly conquered populations they had to police and govern. Reports about their political organizations, religious beliefs, legal customs and languages were vital for the new rulers. Historical information therefore also provided valuable insight into local social structures. Louis Faidherbe, for example, the governor of Senegal from 1854 to 1861, had a personal interest in dialects and histories. Because of this, he promoted local scientific research in line with the cultural and political model of the "bureaux arabes" he had observed in Algeria early in his career. In the 1840s, these administrative offices included Arabists who were assigned the task of gathering information on the native inhabitants. This orientalist legacy was available to the new sub-Saharan colonies, and it provided a number of trained officers who were already fluent in Arabic and versatile enough to learn new local languages. They collected information on the oral traditions of different Senegalese and Sudanese regions, producing studies and articles on a range of topics, including ethnography, geography, linguistics, and history. From this perspective, "the direct line of descent from history written by officers in North Africa and officers in Black Africa is quite obvious." 8

Faidherbe created two journals in 1854, L'Annuaire du Sénégal et dépendances and the Moniteur du Sénégal et dépendances, which both published essays on Senegal's precolonial past, ethnography, and geography. A few decades later, Governor Gallieni, whose early career had started in Senegal, did something similar in the recently colonized Madagascar: in 1902, he established the Académie malgache, whose Bulletin published historical research on a regular basis. ${ }^{9}$ 


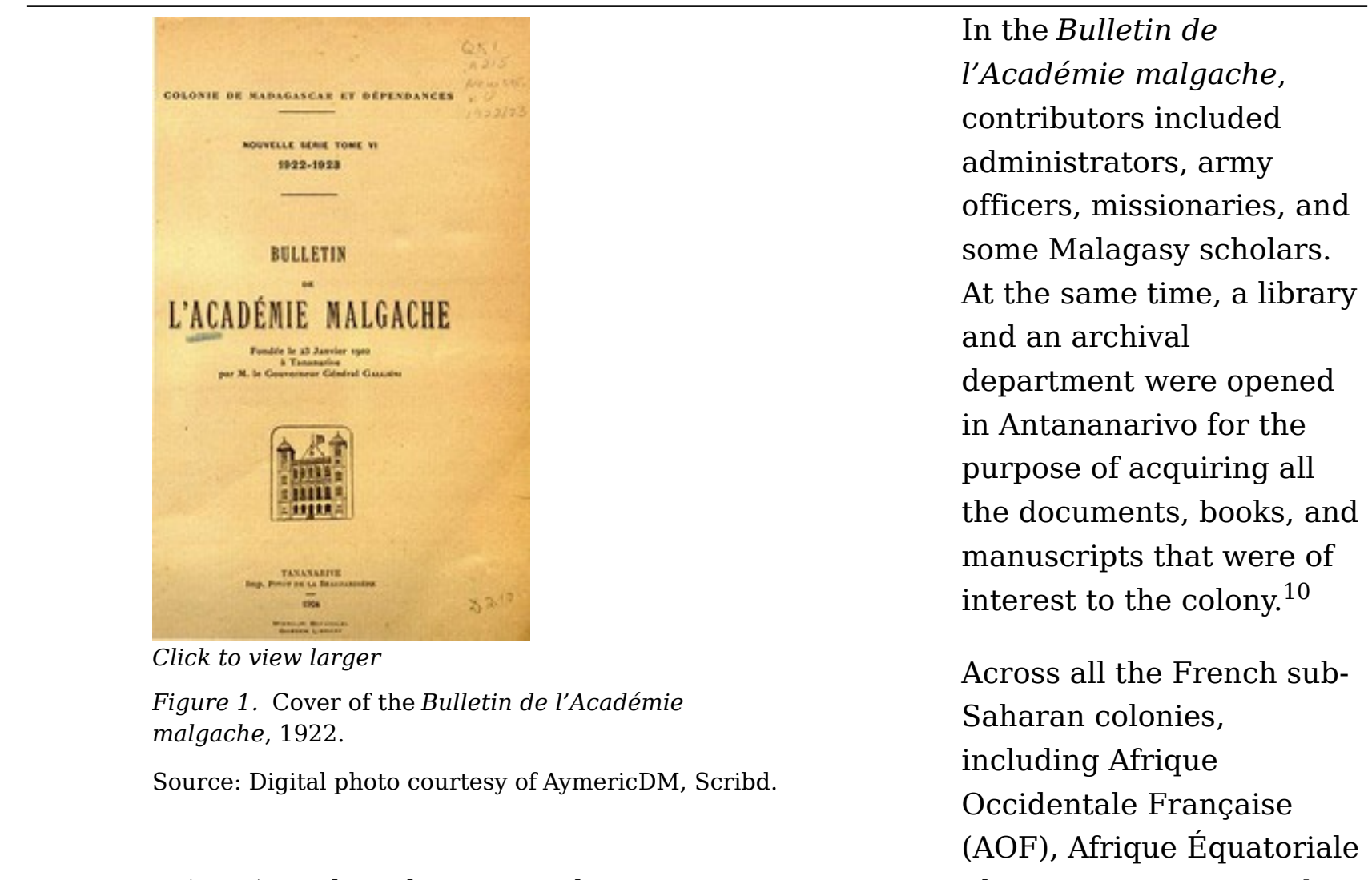

Française (AEF), and Madagascar, administrators were expected to write a monographie de cercle, an extensive study of the district they were in charge of, including from a historical perspective.

Moreover, the decade 1910 to 1920 saw initiatives to organize and classify colonial public records. In Paris, Eugène Saulnier was in charge of classifying all colonial archives created prior to 1895. In the colonies, many administrators (administrator Thévenin in Dahomey, Governor General Clozel in French Sudan, and Governor General Willam Ponty, among others) had begun to raise concerns about the deplorable state of the archives in French Africa and to call for a systematic organization of the colonies' public records. In 1911, William Ponty hired Claude Faure, a professional archivist trained at the École des Chartes, to oversee the central AOF archives in Dakar. In 1922, the "well-known administrator-scholar" Georges Hardy painted a humorous portrait of these new archivists as they confronted colonial realities. ${ }^{11}$ Initial problems included the fact that the premises intended to house the public records had not yet been built, that no proper budget had been assigned, that tropical humidity and termites frequently destroyed the files, and that the colonial administrations were inclined to hamper any initiatives. ${ }^{12}$

Nevertheless, in both Paris and the colonies, documents started to become available for prospective historians eager to learn more about the colonial past. These archives were, however, primarily produced by colonizers themselves; they provided information to those interested in the history of European contacts in Africa; of European explorers, travelers, and conquerors; and of the establishment of colonial rule. This is not surprising in a period when the popular histoire méthodique (positivist historiography) prevailed at the Sorbonne and was primarily focused on political, military, and diplomatic history. William 
Ponty himself justified the conservation of public records in the AOF in terms that would have been very familiar to historians of the Sorbonne in the late 19th and early 20th century-ensuring access to authentic, original sources, the glorification of military and colonial expansion, and the preservation of testimonies about national heroes. ${ }^{13}$

Moreover, colonial archivists also occasionally preserved "indigenous" archives (those directly produced by native authorities). The concern for local sources was not anecdotal, but rather it belonged to a tradition of orientalist scholarship and "Oriental" manuscript collections in Europe. Such was the case, with a version of the Tarikh el-Fettach, a chronicle of the Songhay empire written in Timbuktu in the 17th century, discovered by Albert Bonnel de Mézières in 1911, translated into French by Octave Houdas in 1913, and preserved in Paris in the Bibliothèque Nationale de France. ${ }^{14}$ Another example is the purchase of Toucouleur sultan Ahmadu Tall's archives by the Société de Géographie de Paris in $1924 .^{15}$

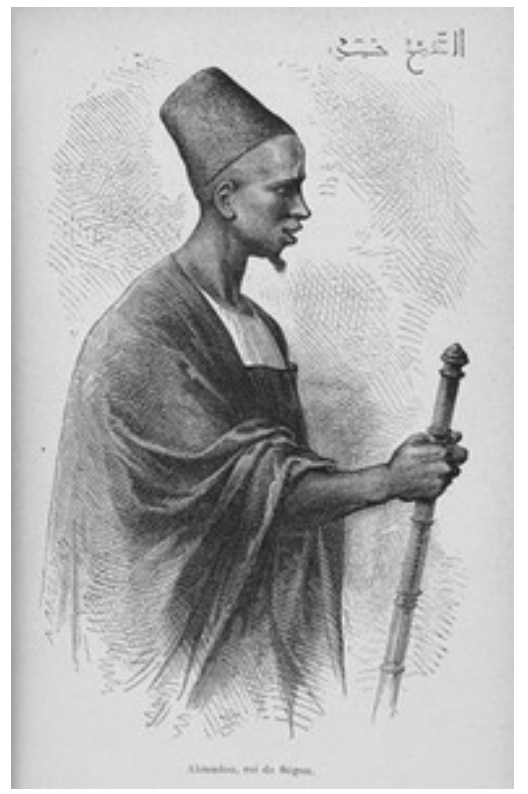

Click to view larger

Figure 2. Portrait of Ahmadu Tall, 1885.

Source: Photo by Camille Pietri. Courtesy of Schomburg Center for Research in Black Culture, Jean Blackwell Hutson Research and Reference Division, Sc 966.2-P.
Likewise, Johannès

Tramond, a professor of colonial history in the École Navale and a prominent member of the Société d'Histoire des Colonies Françaises, vehemently urged "passionate" administrators and army officers serving in French Soudan to seek and preserve all the indigenous papers they could find. He also asked colonial governors to open the AOF and AEF archives to accommodate these new finds which, in his opinion, naturally belonged there, and helped to write the

glorious history of French conquest of their Sudanese regions. ${ }^{16}$

Colonial history, built on the histoire méthodique scientific paradigm that relied on official sources, was thus intended to legitimize French imperialism. In 1921, in one of the first theoretical essays on colonial history, Georges Hardy emphasized the professional ambition of the new field and insisted on its practical dimension for all administratorsfor instance, knowing local history was an invaluable asset to identify ruling aristocracies, to understand the political background and religious rivalries, etc. Thereby Hardy shaped an ambiguous scientific ideal: colonial historians should be scholars serving the interests 
of imperial action. In other words, he revealed the tensions between scientific ambition and political purpose. Henceforth, in his eyes, the ideal colonial historian should be an impeccable scholar who could critically analyze sources and had extensive experience in the colonial field. From this perspective, Maurice Delafosse would have seemed to be the absolute embodiment of such an ideal. ${ }^{17}$

\section{Institutionalizing Colonial History in French Academia (1890s- 1930s)}

As Pierre Singaravélou pointed out, intense lobbying promoted the pursuit of colonial sciences throughout the empire: "The Colonial Ministry, various Governments General, local municipal councils and chambers of commerce, and the colonial lobby funded the colonial sciences, hoping to attract talented youth to careers in the empire and to win over public opinion. A larger nébuleuse of Parisian, provincial, and overseas learned societies, colonial research institutes, publishers specializing in colonial subjects, and scientific journals provided the intellectual spaces, erudite forms of sociability, and peer review that any new discipline requires to professionalise."18

The initial reaction was the foundation of a network of journals, learned societies, and academies devoted to the enhancement of scientific research in French African colonies, following the model previously established in Algeria. The Académie malgache was one of the first scientific circles created outside North Africa and Indochina, although others quickly followed. For example, in French West Africa, a Comité d'Études historiques et scientifiques de l'AOF (Committee for AOF Historical and Scientific Research) was set up in December 1915 under the patronage of the governor general, François Joseph Clozel. Similarly, a group of active scholars (half of them researchers and half administrators, including Clozel himself, Maurice Delafosse, Paul Marty, and Georges Hardy, among others) initiated and encouraged the publication of articles in the Bulletin $d u$ CTHS de l'Afrique Occidentale française.

Most of the scientific books published about African history, geography, ethnography, linguistics, and so on, were manufactured at the official Government General printing facilities. In 1922, Victor Augagneur, the governor general of the AEF, applied a similar structure in Brazzaville with the Société des Recherches congolaises (Society for Congolese Research), which also had a Bulletin.

In 1913, in Paris, Alfred Martineau established the Société d'Histoire des colonies françaises along with its journal, the Revue de l'Histoire des colonies françaises. The society soon became a central hub that connected historians in metropolitan France and in the colonies, with a network of correspondents, contributors, and subscribers. This network was also closely linked to the "Parti colonial" (an alliance of politicians and businesses promoting colonial interests in Parliament and in the media), as well as to the social and political spheres inhabited by high-level colonial administrators. As such, the society ultimately comprised individuals with a variety of backgrounds and experience 


\section{Writing African History in France during the Colonial Era}

(scholarly, administrative, political) who were united by a common interest in colonial matters. It played a prominent role in the promoting colonial studies in France, especially colonial history, which reflected the scientific and academic landscape of the period. With the recruitment of various "Africanists," such as Delafosse and Hardy, the Société d'Histoire des colonies françaises positively contributed to the development of African studies.

However, it was one thing to promote historical research on and in the colonies-it was quite another to gain the full recognition of colonial history among first-rate academic circles. In metropolitan France the process of institutionalization had started as early as the 1890s. Certain positions were desirable, notably at the Sorbonne University or at the highly prestigious Collège de France. Other academic institutions were certainly less prestigious, for example, the École coloniale (created in 1889 to train colonial administrators) and the École nationale des Langues orientales vivantes (an old institution that trained interpreters, reorganized in 1914), but were nevertheless responsible for establishing colonial history in some academic circles. In 1926, "a longdreamt of Académie des sciences coloniales was created to coordinate colonial research efforts and offer advice to overseas governments," following the model of the old Académie des Sciences created in the 17 th century. ${ }^{19}$

Several university chairs were founded in Paris. The geographer Marcel Dubois and his colleague Henri Pigeonneau pushed to hold a class on colonial history at the Sorbonne; this class was experimental at first, from 1899 to 1892, without a full recognition in academic terms. Then the Sorbonne faculty members decided to officially promote colonial sciences: a chair of colonial geography was created in 1893, and an additional maîtrise de conférences in colonial history was opened in 1905, with Prosper Cultru as the first appointed professor. ${ }^{20}$ Although this chair would not be maintained after Cultru's death in 1919 (and was not realized again until 1942), their initiative proved to be at least partially successful between the 1890s and 1910. After a long and difficult fight, and despite the reluctance of many academic historians, in 1921, Alfred Martineau (a former colonial governor and a specialist in French colonial India) was elected as professor of colonial history at the Collège de France. This marked the official institutionalization of the subject in the core of French academia. In this case, the chair was funded with money from Indochina and the AOF and AEF Governments General, and was openly called for by the minister of colonies himself, Albert Sarraut. ${ }^{21}$

By the end of the 1930s, colonial sciences in general, and colonial history in particular, had embedded itself across many different levels of academia. Besides bastions such as the Sorbonne and the Collège de France, colonial history was also taught in more provincial institutions, such as the Faculté des Lettres in Poitiers and Bordeaux. It was similarly well established in Paris, at the École coloniale, the École des Langues orientales, and the École Libre des sciences politiques. At the École coloniale, in particular, a specialization in African studies (section africaine) was created in 1892, introducing the students to languages, civilizations, and history under the supervision of Maurice Delafosse, who from 1918 to 1926 also offered a class in African history at the 
École des Langues orientales. In 1926, Georges Hardy became director of the École coloniale and reinforced the curricula with different classes on ethnography, linguistics, and history, which attracted new professors.

In the wake of the successes achieved by colonial sciences, the fields of African studies and African history gradually also gained credibility, although it was initially difficult for them to exist independently from the global framework of colonial history.

\section{Knowledge "Nevertheless" (1880s-1950s)}

François Pouillon characterized social sciences born in a colonial context as " $d u$ savoir malgré tout" (knowledge "nevertheless"). ${ }^{22}$ The phrase helps us to re-examine the notion of "colonial science," to reassess the scientific dimension of this specific kind of knowledge, and to understand the complexity of its elaboration. Alice Conklin, in a review of Helen Tilley's book Africa as a Living Laboratory, pointed out that

all scientific research circulates both locally and globally in ways that its producers cannot control-even when this research is sponsored by imperial governments seeking solutions to problems of colonial governance. From this perspective, defining any "science" as specifically "colonial" obscures more than it illuminates. [The] point is not that "good" science triumphed over "bad" science in Britain's African colonies, but that the outcome of the appeal to science was never absolutely predetermined by the fact of empire. Professionalizing scientists in the field could and often did maintain their distance from policymaking: their training encouraged them to look for the very kind of complexity in human societies that overburdened administrators or their superiors did not have time to consider."23 


\section{European Expansion History or African Societies' History?}

Conklin's analysis can be similarly applied to colonial history, African studies, and the history of Africa in the late 19th century and first half of the 20th century. Much of their contents were shaped by colonial logic, but one should not underestimate the advancements made by some of the best scholars or the innovation they promoted.

Undeniably, a large part of colonial historiography included imperialist self-glorification. Colonization was commonly seen as a necessary, universal, and natural fact, an inevitable stage in the global development of societies and a "mission to civilize" for superior nations. Several studies were centered on the activities of Europeans, without regard to African societies themselves. For instance, the first doctorate in colonial history defended at the Sorbonne, by Étienne Berlioux, was about André Bruë, a tradesman and explorer who was active in the Senegal region in the 17th and 18th centuries. During the Exposition Universelle, organized in Paris in 1900, the Colonial Ministry commissioned the Sorbonne geographer Marcel Dubois and Auguste Terrier, an active member of the Comité de l'Afrique française, to write a thousand-page book about the French empire. The first volume was devoted to the history of French expansion in the world, and several chapters focused on sub-Saharan Africa before and during the colonial conquests. The evocation of precolonial states had one main purpose: to highlight the heroism of French soldiers and officers and to emphasize France's civilizing mission and endless efforts to bring peace and prosperity to millions of Africans. ${ }^{24}$

There exist numerous similar examples of this Eurocentric approach. ${ }^{25}$ In 1906, for instance, Prosper Cultru's book An Emperor of Madagascar in the Eighteenth Century was not a study of the Merina monarchy, but a biography of the Austro-Hungarian explorer Baron Benyowszky. ${ }^{26}$ Georges Hardy's doctoral thesis explored Senegal's colonial development ("mise en valeur") from 1817 to 1854. Even when their curiosity was drawn to Africa's past, the authors predominantly considered that the continent's evolution had inexorably paved the way for European rule. Hence a propensity to offer analysis, approaches, and reading grids to convey the idea of Africa's long-term passivity grew. This passivity was often accounted for in terms of climate, race, and collective psychology. Georges Hardy, in 1922, in a book offering a general survey of Africa's history, asserted that "climate-historical" zones, meaning climatic regions in which different "historical styles" had developed, could be observed. According to some implacable determinism, large empires had flourished in the region that connected the Saharan climate with the Sudanian climate, whereas only powerless societies had established themselves in the equatorial climate zone and its suffocating forests. ${ }^{27}$ Moreover, races were seen as the "daughters of climate"; population movement had been quite uncommon in ancient Africa because of climatic zoning, which prevented biological crossbreeding and cultural mixing. In Hardy's eyes, crossbreeding (métissage) was essential for the development of nations-and nations were the only powerful historical agents. Thus Africa, a land of isolation, with poorly mixed races, was condemned to inertia until European nations colonized the continent. ${ }^{28}$ Confronted with the evidence 
that powerful dynamic movements had occurred in Africa's past (conquests, wars, statebuilding processes, and cultural and trade exchanges), some historians assumed that only exterior interventions could explain it. For example, the West African Fulbe (creators of successful states in the 18th and 19th centuries) could only have been non-Africans, probably of "Hamitic" descent, and therefore Jewish or Arabic. ${ }^{29}$ Other historical myths, subsequently dismissed, insisted on the journey of the Carthaginian sailor Hannon in the Guinean Gulf in the 3rd century BC or the discovery of Guinean coasts by Dieppe merchants in 1364.

Sometimes, practical decisions were directly based on historical information. In Madagascar after 1895, the new governor general was referred to as the successor of the Merina sovereign: like him or her, he demanded unpaid labor from his "subjects," presided over similar ceremonies, and used royal symbols. In the Afrique Occidentale Française (AOF) federation, the search for ancient chronicles and genealogies was often a way to promote and legitimize special groups or leaders who were allied with the French. Similarly, the exaltation of "medieval" states such as Mali or Ghana was a way to assert the value of the colonized peoples, whose former glory reflected back on colonial France.

But it would be an exaggeration to see colonial historiography only as glorifying imperial power and "superior races" or being merely instrumental of the past. It was a hybrid production, which, in its own way and in its specific intellectual context, contributed to historicizing African societies, to accumulating information about their pasts, and to forging methodological tools. In fact, as Conklin writes, "In contrast to geographers, only a small subset of professional historians developed an interest in the history of colonialism. Eurocentric and always pro-empire, these experts were also among the first in France to study 20th-century and oral history, and to challenge the racial determinism of conservatives at the Sorbonne."30

\section{The "Invention" of Native History (Histoire Indigène) as a Scientific Co-production}

Officially, the motivation for collecting information about the history of native inhabitants was to know them better so as to govern them more effectively. Yet, as Emmanuelle Sibeud pointed out in her research on French africanisme, "colonial administrators nurtured an erudition level that far exceeded the pragmatic demands of colonial governance." 31 In fact, though the authorities encouraged research, they expected practical facts, not extensive knowledge on ancient African societies. However, amateur archaeologists, including administrators, military men, and traders, such as Bonnel de Mézières, started to look for ancient civilizations and cities. ${ }^{32}$ Passionate amateurs sometimes conducted historical inquiries in their spare time and acquired a great deal of knowledge. In 1970, Raymond Mauny, then a prominent historian and a professor of ancient African history at the Sorbonne, paid tribute to the colonial scholars Yves Urvoy, 
Maurice Delafosse, Charles Monteil, Georges Hardy, Henri Labouret, Henri Gaden, and others who "had not waited for the independence era to study the Africans' history per se, with no consideration for exterior agents."33

As early as 1911, for instance, the colonial administrator Auguste Le Hérissé published an extensive study on the ancient Kingdom of Dahomey, which collected oral sources and presented the genealogies, banners, and mottos of the Dahomeyan kings since 1620 . Similarly, the work by Maurice Delafosse was the most famous example of colonial scholarship on African history.

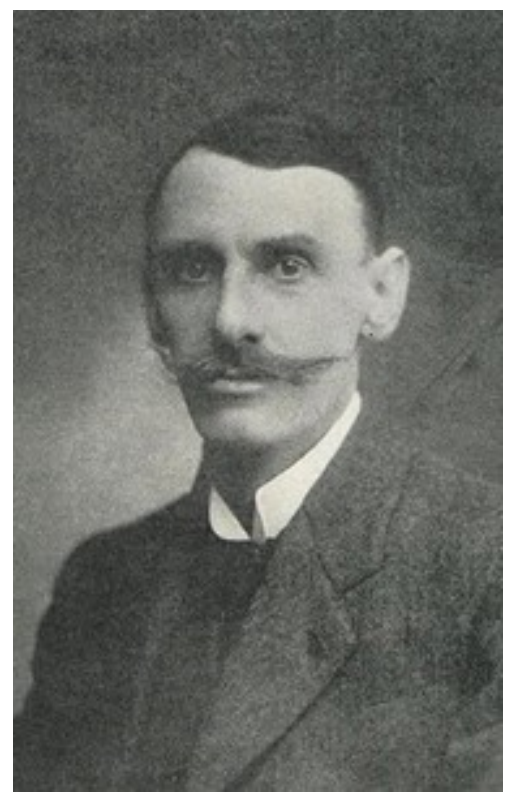

Click to view larger

Figure 3. Portrait of Maurice Delafosse, 1924. Wikimedia Commons, public domain.
Born in 1870, Delafosse had studied Arabic in Paris in his early years and had learned several African languages while serving as a colonial administrator in AOF from 1894 to 1918. Fascinated by ethnology and history, and eager to promote historical research in the colonies (he belonged to the Comité d'Études historiques et scientifiques de l'AOF), he started to collect information, notably, for his first substantial research work

Monographie historique du cercle de Bamako (1910). Haut-Sénégal Niger, published in 1912 , is commonly considered to be the founding text of French africanisme. ${ }^{34}$ It offers a comprehensive survey of Western Sudanese history, in fifteen chapters covering thirteen centuries. His primary sources, both written and oral, were diverse, and his powerful narrative was packed with dates and factual details. Even if today some scholars are very critical of Delafosse's "masterpiece" (Pekka Masonnen, for example, considers HautSénégal Niger to be much less accurate than Cooley's Negroland of the Arabs despite the fact that Cooley's book was written seven decades earlier), the French scholaradministrator was nevertheless considered a major specialist in African history in his own time. ${ }^{35}$ His early retirement from colonial administration (in part because of a lack of support from his superiors for his scientific pursuits) enabled him to start a second career after World War I. His strong existing connections to colonial circles in Paris were key to enhancing his intellectual influence, as was the fact that he was less and less considered a field historian lost in distant Africa, and more and more a respected orientalist working in the heart of French academia. He was invited to teach the Mandinka language at the 
École des Langues Orientales, and soon joined the École Coloniale as a permanent professor, remaining there until his death in 1926.

Some other pioneers of African history are not as well known as Delafosse, despite the quality of their research. Charles Monteil belongs in this category; also a colonial administrator, he served in the AOF from 1893 to 1904 before returning to France, where he wrote extensively on his historical discoveries. He spent eighteen months in the Djenné cercle (district of Djenne) in 1901, where he collected an impressive range of data, met with all the dyeli and scholars he could find, and created eight hundred different files for keeping track of his interviews his African "informants." Monteil used this empiric material for two of his most important books: Les Bambara de Ségou et du Kaarta (1924) and Les empires du Mali (1929). He developed a sharp critical framework for dealing with oral sources and Sudanese chronicles long before the historians of the 1960 s did. In so doing, he offered a nuanced, rich reflection on the frailty of "tradition"; the importance of informants' social positions, which could, notably, modify their so-called traditional narratives; the process of westernization already developing at the time; and the changes that were inevitably produced when oral material was recorded in writing. ${ }^{36}$

As one can see, there was a rapid emergence of what was then called "histoire indigène" (native history) in the very matrix of colonial historiography. Moreover, behind the writings of European authors about the Merina monarchy in Madagascar, the Massina, or El Hadj Umar Tall's empire, the presence of African scholars can be glimpsed. Partnerships between a European scientist and an African "informateur" (informant) or "lettré" (scholar), as they were called, were quite common. Bonds between researchers and collaborators were formed according to circumstances and affinities: Monteil and Tamura Koré or Garan Kuyaté, Henri Gaden and Cheikh Moussa Kamara, Delafosse and Travélé or Abdoulaye Kane, Hardy and Mapaté Diagne, and many more. ${ }^{37}$

African researchers gradually emerged, though colonial scientists, journals, and publishers still did not consider them authorized scholars. Some took up the pen very early, such as the Wolof "chief" Yoro Dyaô who, in 1864, wrote the first Histoire du Cayor. ${ }^{38}$ In the interwar period, local dignitaries, schoolteachers, interpreters, and colonial clerks became occasional contributors to journals and publications. In particular, the case of schoolteachers contributing to historical investigations is interesting. Since the 1910s, these westernized elites, trained at the École normale William-Ponty in Senegal, were invited to make thorough historical and ethnographical inquiries about their native villages or the posts they were transferred to. Under Jules Brévié's governance in the 1930s, such inquiries became systematic, under the supervision of rural teaching colleges (écoles normales rurales). Teams of schoolteachers thus provided data to colonial researchers in a coordinated scientific effort, seeking information about documents, texts, and oral sources, while still maintaining a clear division of the intellectual labour. Some of them also started to write on their own, including Siré-Abbas Soh, Rawane Boy, Cheikh Moussa Camara, and Jean-Pierre Sarr in Senegal; Maximilien 
Quenum in Dahomey; and Antoine Dim Delobsom, Mamby Sidibé, Biraim Ciré Bâ, and Dominique Traoré in Haute-Volta. ${ }^{39}$

Quenum, the author of a study about Dahomey in 1936, made fun of the European scholars who were naive enough to believe the stories their local informants told them. In his opinion, princes and former ministers would never reveal any potentially embarrassing information to a foreigner, nor would they accurately describe any institution. ${ }^{40}$

However, being an African did not necessarily guarantee understanding: as members of the elite, or as individuals belonging to a particular socio-ethnic group, numerous African authors and informants struggled in their own ways to distinguish truths from falsehoods. Moreover, their own social positions were often far from neutral, and they contributed to the shaping of historical narratives according to their views and interests accordingly. Referring to the Nigerian case, Paul Zachernuk coined the phrase "colonised collocutors," to describe such African intermediaries. ${ }^{41}$ In several cases, their specific vision of history was arbitrarily inserted into colonial scientists' studies. ${ }^{42}$ To some extent, the African past was perceived by African eyes through European glasses, yet also by European eyes through African glasses. ${ }^{43}$ Regardless, it is important to recognize that even during colonial times, despite the fact that historiography was the exclusive domain of colonial agents, it was nevertheless still possible for some members of the African elite to influence the recording of narratives and "traditions."

\section{Declining Colonial Science, Rising African History (1945-1960)}

Since the 1930s, in some cases, and more so since the end of World War II, changes began to take place. In African colonies, new scientific initiatives began to take root, especially in AOF where, in August 1936, Governor General Brévié created the IFAN, Institut français d'Afrique noire (Black Africa French Institute). This foundation reflected a new public policy regarding science in the colonies and was granted many more resources than its predecessor, the Comité des Études historiques et scientifiques de l'AOF. A team of permanent researchers (mostly specialists in "natural sciences" but also several social scientists) were paid from the AOF budget. Gradually, several Centrifans (IFAN branches) were established in the colonies of French Africa. In AEF, the Société d'Études camerounaises was created in 1935, showing some interest in historical matters, whereas the activities of the Société de Recherches congolaises had significantly slowed down in the 1930s.

Everywhere, colonial history was less and less in vogue. In metropolitan France, after a peak in interest in 1931 during the Exposition coloniale in Paris, colonial historians suffered several setbacks. In 1937, the chair in the history of colonization at the prestigious Collège de France was renewed, and the position was filled by Edmond Chassigneux, but only after a great deal of difficulty. During the election process, Lucien Febvre, a prominent historian belonging to the Annales School and a member of the 
Collège faculty, was critical of the very concept of "colonial history." In his eyes, the Collège de France was there to promote new disciplines and new scientific fields, not more old-fashioned forms of science now in decline. ${ }^{44}$ In 1947, after Chassigneux had retired, in 1947, a new election took place. Lucien Febvre's leadership was even more effective than it had been ten years before; he changed the name of the chair (Histoire de la colonisation became Histoire de l'expansion de l'Occident); the new title expressed the will to dissolve colonialism and imperialism into something more wide-reaching with a greater global perspective. Moreover, Febvre, with Charles-André Julien (a specialist in Maghreb) at his side, advocated the notion that the history of colonized societies should be incorporated into the broader field of political, economic, and social history promoted by the Annales School. In so doing, he demonstrated that colonialism was now viewed as a historical phenomenon like any other. With the election of Robert Montagne at the Collège (Montagne was a sociologist-ethnologist rather than a historian and a specialist in Berbers, whose ideas about the social sciences were close to those of the Annales), the intention was to showcase non-western populations, even if the new name of the chair suggested otherwise. Febvre finally pronounced the death of colonial history when, writing to the faculty members, he told them they had done well in rejecting "the old, sterile, sleepy conception of colonial history," which was an anecdotal "school-based form of history" lacking substance and methodology. 45

Febvre's vision is understandable in the context of French history renewal after World War II, and of the Annales School's success and institutionalization. It was also a new era politically, one in which the imperial consensus of the interwar period came to an end. Colonial sciences became even more marginalized than they had been at the end of the 1930s. They became were more closely associated with colonial nostalgia and endured only in school curricula into the 1950s.

As far as the history of Africa was concerned, even former colonial administrators like Hubert Deschamps or Raymond Mauny became full-time scholars. The former, well connected to international institutions such as the African International Institute based in London and the London School of Oriental and African Studies, continued with a rather classical vision of history, in which French expansion was still the central narrative. The latter became a respected specialist in ancient Africa. Between them they held the first two university chairs in "African history" to be opened in France, at the Sorbonne, in 1962 and 1964.

In the same period, Henri Brunschwig, a friend of Braudel's, was appointed senior researcher at the sixth section of the École Pratique des Hautes Études (the soon-to-be École des Hautes Études en Sciences sociales, an avant-garde academic institution, and a bastion of the Annales). Georges Balandier, a famous sociologist, also had great influence on the young generation of African historians trained in the 1960s, such as Catherine Coquery-Vidrovitch, Claude-Hélène Perrot, and Henri Moniot. A Parisian network of social scientists emerged, including Balandier, Gilles Sautter, and Denise Paulme, which had a great deal to share with the historians of Africa in, for instance, the journal Cahiers d'Études africaines, created in the late 1950s, and in the seminars held at the École 
Pratique des Hautes Études. Together, they contributed to the emergence of African studies in France, a "cultural area" approach, new at the time, that enabled the development of high-level historical research in continual dialogue with other social sciences. "Outsiders" were also active, especially Marxist historians such as Jean SuretCanale and Pierre Boiteau, though their influence in the academic context remained rather limited.

More importantly, African historians and intellectuals appeared and significantly began to challenge European scholarship. Despite all the controversies it caused in the field of Egyptology and beyond, Cheikh Anta Diop's defense of his doctoral thesis at the Sorbonne, in 1960, was a landmark moment for many African students and for the Afrocentric conception of history. ${ }^{46}$ Abdoulaye Ly is less famous than Diop, but he nevertheless played an important role in the emergence of professional scholarship in francophone Africa. Born in 1919 in Saint-Louis-du-Sénégal, to a westernized elite family, Ly studied history in France before being appointed to the IFAN, in Dakar, in 1952. In 1955, he defended his thesis in Bordeaux, becoming the first francophone West African to earn a doctor of philosophy degree in history, and went on to supervise the research of numerous students after Senegal gained independence ${ }^{47}$ In other former colonies, a new generation of historians emerged in the 1950s and 1960s, including Boubou Hama in Niger, Joseph Ki-Zerbo in Haute-Volta, Sékéné Mody Cissoko in Mali, and Djibril Tamsir Niane in Guinea. Together they helped transform, reshape, and internationalize African historiography during the period of African independences. They shared with young French historians of Africa the conviction that colonial historiography was dead and buried, and that a new field was now to be explored.

\section{New Perspectives around 1960}

Substantially weakened after 1945, colonial history gradually faded away, culminating in the loss of most of the institutional positions in the field that had been fought for at the beginning of the century. In all its diversity and contradictions, it had been the exotic branch of French mainstream historiography, a playground for amateur and professional historians, as well as a laboratory for innovative methodologies and early interdisciplinary practices. In short, colonial history existed as an imprecise component of "the colonial (scientific) empire," but also as a territory cleared for new discoveries. ${ }^{48}$

Far from having been established in the aftermath of independences, a useful myth promulgated by a rising generation of French and African academic historians after 1960, African history (as in history centered on African societies per se) had hesitantly found its way during the colonial era. Reconnecting with a long precolonial scholarly heritage, it broke out of the mold in which it had been trapped in the 19 th century. ${ }^{49}$ A more accurate vision of the African past emerged in the process, breaking with the common idea that the continent had no history. Along the way, new methods and sources were invented, and 
knowledge, often co-produced by African scholars, was accumulated for the next generation of historians, whose careers blossomed after the independences.

\section{Discussion of the Literature}

An immediate difficulty regarding "African history" (or "history of Africa") lies in the potentially diverse definitions given to this simple phrase and, to an even greater extent, to colonial historiography. Whereas it is relatively simple to understand what "English history" (or "history of England") is, defining the exact scope of "African history" proves more troublesome. John Fage, as well as many other prominent authors, considers that "African historiography is as old as the writing of the discipline itself." 50 Other historians assert that it could emerge only after the independence of African countries in the 1960s. ${ }^{51}$ The latter perspective is thus based on multiple criteria meant to encapsulate its authenticity: the period in which it was written, the use of oral sources, the study of exclusively Afro-centered subjects, and, in some instances, even the requirement that the historian be an African. ${ }^{52}$

These claims raise epistemological and historiographical questions, since features other than the specific scientific objects studied are considered in defining an academic field. Unquestionably, such visions tend to disqualify colonial historiography in its entirety, which is problematic from a pragmatic perspective: since 1960, many historians have carried on citing colonial scholars and colonial studies, sometimes openly, but often in the guilty way Fanny Colonna described (see Note 2). Not only do the purist definitions of African history oversimplify the knowledge produced before the independence era, but they also consider the origins of all colonial scholarship as taboo.

Yet, as Bourdieu said of sociology in a colonial context, "l'inconscient d'une discipline, c'est son histoire" (the subconscious of a discipline is its history). ${ }^{53}$ For this reason, an overall reflection on French colonial knowledge was launched in the 1970s by Henri Moniot, Jean-Claude Vatin, Gérard Leclerc, Daniel Nordman, Jean-Pierre Raison, and many others. ${ }^{54}$ Those pioneering studies essentially focused on sociology, anthropology, and ethnography in the Maghreb, discussing imperial episteme and the validity of colonial sciences. ${ }^{55}$ Since then, additional studies on French sciences in imperial and colonial contexts have been conducted by Véronique Dimier on political science, Pierre Singaravélou on imperial knowledge in general, and Hélène Blais and Florence Deprest on geography and cartography. ${ }^{56}$ The African field has concentrated some interest with seminal studies on africanisme by Emmanuelle Sibeud, Anne Piriou, and Marie-Albane de Suremain. ${ }^{57}$ Research on colonial social sciences has thus highlighted their numerous biases and the entanglements between scientific, imperial, and colonial agendas. These studies have partially deconstructed the oversimplistic view of the sciences as a constant tool used by authorities; they have also undermined the common idea that scholars embedded in colonial contexts produced utterly "bad" science. The very concept of 
"colonial science" has been discussed and criticized, re-evaluating its heuristic relevance. ${ }^{58}$

Colonial scientific realities were complex, as was the case with history. As Henri Brunschwig, Abdoulaye Bathily, and Monique Lakroum started to do as early as the 1960s, Dulucq, in her book on French colonial historiography, sheds light on the gradual genesis of African history in France, demonstrating some continuity between preindependence and post-independence periods. ${ }^{59}$ The study develops many aspects addressed here in general terms. It evaluates, on the one hand, how scientific discourse was dependent on individuals and specific contexts, but also how, on the other hand, it preserved a certain depth, which kept it autonomous from the very conditions of its production.

\section{Primary Sources}

In order to study sub-Saharan African historiography during colonial times, one needs to browse the shelves of the "colonial library" and open the hundreds of books, articles, and diverse texts produced between the late 19th century and the end of the 1950s.

Complete collections of scientific journals are available at the Bibliothèque Nationale de France $(\mathrm{BnF})$ and in the libraries of several French universities. Many of them can be easily consulted online in the digital collections of the BnF (Gallica) or of the Smithsonian Institute (Smithsonian Libraries) ${ }^{\mathbf{6 0}}$ Historical research was published in numerous colonial journals, including the Revue de l'histoire des colonies françaises (1913-1932; subsequently renamed Revue d'histoire des Colonies and published from 1932 to 1960); the Annuaire des Travaux historiques et scientifiques de l'Afrique Occidentale Française (1916-1917), renamed Bulletin des Travaux historiques et scientifiques de l'AOF (19181937), and ultimately became Bulletin de l'Institut français d'Afrique noire (1938-1960); the Bulletin de la Société des recherches congolaises (1922-1937); and the Bulletin trimestriel de l'Académie malgache, renamed Mémoires de l'Académie malgache (19021960). Along with the journals published in metropolitan France and in the colonies, a significant number of books on the history of colonial Africa were published from 1880 to 1960. Numerous publications dealt with the history of colonization in Africa or included chapters on the subject. Approximately thirty books were exclusively devoted to the socalled native history.

Going through these journals and books provides a comprehensive insight into the historical knowledge on Africa that emerged during colonial decades, with all its strengths, flaws, and weaknesses. In addition to such scholarship, a dozen doctoral theses on African history were defended at the Faculté des Lettres de Paris (Sorbonne) or in other French universities, the first dating back to 1874: Étienne Berlioux, "André Brue ou l'origine de la colonie française du Sénégal avec une carte de la Sénégambie" The doctoral theses themselves can be consulted at the Sorbonne library, and the French 
National Archives provides scientific reports and administrative documentation about the doctoral defenses (ANF, Série F 17: "Faculté des Lettres de Paris, Rapports de thèses").

Finally, the public records of the Collège de France (série G IV, “Délibérations des Professeurs") give an interesting perspective on the sometimes heated debates that surrounded the creation of colonial history chairs and the nominations of new professors from 1921 to 1947.

\section{Further Reading}

Afigbo, Adiele E. “Colonial Historiography." In African Historiography: Essays in the Honour of Jabob Ade Ajayi. Edited by Toyin Falola, 39-51. London: Longman, 1993.

Amselle, Jean-Loup, and Emmanuelle Sibeud, eds. Maurice Delafosse: Entre orientalisme et ethnographie, l'itinéraire d'un africaniste (1870-1926). Paris: Maisonneuve and Larose, 1998.

Bathily, Abdoulaye. “Aux origines de l'africanisme: Le rôle de l'œuvre ethno-historique de Faidherbe dans la conquête française du Sénégal." In Le Mal de voir: Ethnologie et orientalisme, politique et épistémologie, Cahiers Jussieu $n^{\circ} 2$. Edited by Henri Moniot, 77107. Paris: Union Générale d’Édition, 1976,

Boulègue, Jean. "À la naissance de l'histoire écrite sénégalaise: Yoro Dyao et ses modèles ( $2^{\mathrm{e}}$ moitié du XIX ${ }^{\mathrm{e}}$ siècle-début du XX $\mathbf{X X}^{\mathrm{e}}$ siècle)." History in Africa 15 (1988): 395-405.

Brunschwig, Henri. "French Historiography since 1945 concerning Black Africa." In Reappraisals in Overseas History: Essays on Post-War Historiography about European Expansion. Edited by Peter Emmer and Henri Wesseling, 84-97. Leiden, the Netherlands: Leiden University Press, 1979.

Conklin, Alice. “What Is Colonial Science?” Books and Ideas, January 31, 2013.

Cooper, Fred. "Decolonizing Situations: The Rise, Fall and Rise of Colonial Studies (19512001)." French Politics, Culture and Economy 20, no. 2 (2002): 47-76.

Dulucq, Sophie. Écrire l'histoire de l'Afrique à l'époque coloniale (XIXX ${ }^{e}-\boldsymbol{X X}^{e}$ siècles). Paris: Karthala, 2009.

Dulucq, Sophie, and Colette Zytnicki, eds. Special issue: "Savoirs autochtones et écriture de l'histoire en situation coloniale ( $\mathbf{X I X} \mathbf{X}^{\mathrm{e}}-\mathbf{X X} \mathbf{X}^{\mathrm{e}}$ siècles). 'Informateurs indigènes,' érudits et lettrés en Afrique.” Outre-Mers: Revue d'histoire 352-353 ( $2^{\mathrm{e}}$ semestre 2006): 7-106.

Gantès, Gilles de. "L'historiographie coloniale et son institutionnalisation." Outre-Mers: Revue d'histoire (1 ${ }^{\mathrm{er}}$ semestre 2003): 7-20.

Hargreaves, John. "From Colonization to Avènement: Henri Brunschwig and the History of Afrique Noire." Journal of African History 31 (1990): 347-352. 
Jewsiewicki, Bogumil, and David Newbury, eds. African Historiographies: What History for Which Africa? London: Sage, 1986.

Labrune-Badiane, Céline, and Smith, Étienne. Les hussards noirs de la colonie. Instituteurs africains et petites patries en AOF. Paris: Karthala, 2018.

Masonnen, Pekka. The Negroland Revisited: Discovery and Invention of the Sudanese Middle Ages. Helsinki: Finnish Academy of Sciences and Letters, 2000.

Maurel, Jean-François. "Les archives de l'AOF avant, pendant et après l'AOF." In AOF: Réalités et héritages. Vol. 1, Sociétés ouest-africaines et ordre colonial. Edited by Charles Becker, Saliou Mbaye, and Ibrahima Thioub, 189-195. Paris: Karthala, 1997.

Moniot, Henri, ed. Le Mal de voir: Ethnologie et orientalisme, politique et épistémologie. Cahiers Jussieu $n^{\circ} 2$. Paris: Union Générale d’Édition, 1976.

Nordman, Daniel, and Jean-Pierre Raison, eds. Sciences de l'homme et conquête colonial: Constitution et usage des sciences humaines en Afrique (XIX ${ }^{e}-\boldsymbol{X X}^{e}$ siècles). Paris: Presses de l'École normale supérieure, 1980.

Piriou, Anne. "Intellectuels colonisés et écriture de l'histoire en Afrique de l'ouest (c. 1920-c. 1945." In Décoloniser l'histoire? De l'histoire coloniale aux histoires nationales en Afrique et en Amérique latine (XIX ${ }^{e}-\boldsymbol{X} \boldsymbol{X}^{e}$ siècles). Edited by Sophie Dulucq and Colette Zytnicki, 659-681. Paris: Publications de la Société française d'histoire d'outre-mer, 2003.

Pondopoulo, Anna. "Une histoire aux multiples visages: La reconstruction coloniale de l'histoire du Fuuta sénégalais au début du $\mathbf{X X}^{\mathrm{e}}$ siècle." Outre-mers: Revue d'histoire 352353 ( $2^{\mathrm{e}}$ semestre 2006): 57-78.

Sibeud, Emmanuelle. Une science impériale pour l'Afrique ? La construction des savoirs africanistes en France, 1878-1930. Paris: Éditions de l’École des Hautes Études en Sciences Sociales, 2002.

Singaravélou, Pierre. Professer l'Empire: Les "sciences coloniales" en France sous la III République. Paris: Publications de la Sorbonne, 2011.

Suremain, Marie-Albane de. "Chroniques africanistes ou prémisses d'une histoire totale de l'Afrique? L'histoire coloniale dans le Bulletin du Comité d'Études historiques et scientifiques de l'AOF/ IFAN, 1916-1960." In Décoloniser l'histoire? De l'histoire coloniale aux histoires nationales en Afrique et en Amérique latine (XIX ${ }^{e}-\boldsymbol{X} \boldsymbol{X}^{e}$ siècles). Edited by Sophie Dulucq and Colette Zytnicki, 39-58. Paris: Publications de la Société Française d'Histoire d'Outre-Mer, 2003.

\section{Notes:}

Page 20 of 25

PRINTED FROM the OXFORD RESEARCH ENCYCLOPEDIA, AFRICAN HISTORY (oxfordre.com/africanhistory). (c) Oxford University Press USA, 2018. All Rights Reserved. Personal use only; commercial use is strictly prohibited (for details see Privacy Policy and Legal Notice). 
(1.) Pekka Masonnen, The Negroland Revisited: Discovery and Invention of the Sudanese Middle Ages (Helsinki: Finnish Academy of Sciences and Letters, 2000), 24.

(2.) Fanny Colonna, "Production scientifique et position dans le champ intellectuel et politique: Deux cas: Augustin Berque et Joseph Desparmet," in Le Mal de voir: Ethnologie et orientalisme, politique et épistémologie. Cahiers Jussieu $n^{\circ} 2$, ed. Henri Moniot (Paris: Union Générale d’Édition, 1976), 399, my translation.

(3.) Anne Piriou and Emmanuelle Sibeud, L'africanisme en questions (Paris: CEAf-CNRS, 1997).

(4.) Valentin Mudimbe, The Invention of Africa: Gnosis, Philosophy and the Order of Knowledge (Bloomington: Indiana University Press, 1988).

(5.) On the discussion on the concept of "colonial science," read the review by Alice Conklin, "What Is Colonial Science?", Books and Ideas, January 13, 2013. She discusses Helen Tilley's book, Africa as a Living Laboratory: Empire, Development, and the Problem of Scientific Knowledge, 1870-1950 (Chicago: University of Chicago Press, 2011).

(6.) Masonnen, Negroland Revisited, 245.

(7.) Pierre Singaravélou, Professer l'empire: Les "sciences coloniales" en France sous la iiie République (Paris: Publications de la Sorbonne, 2011) quoted in Conklin, "What Is Colonial Science?”

(8.) Abdoulaye Bathily, “Aux origines de l'africanisme: Le rôle de l'œuvre ethno-historique de Faidherbe dans la conquête française du Sénégal," in Le Mal de voir: Ethnologie et orientalisme, politique et épistémologie, ed. Henri Moniot (Paris: Union Générale d’Édition, 1976), 79.

(9.) A 1922 issue of Bulletin de l'Académie Malgache, vol. 6 is available online from ScribD.

(10.) Sophie Dulucq, Écrire l'histoire de l'Afrique à l'époque coloniale (xix ${ }^{e}-x x^{e}$ siècles) (Paris: Karthala, 2009), 41.

(11.) Conklin, "What Is Colonial Science?"

(12.) Georges Hardy, Les éléments de l'histoire coloniale (Paris: La Renaissance du Livre, 1922), 12-13.

(13.) Prosper Cultru, “L’organisation des archives du gouvernement général de l'Afrique occidentale," Revue de l'histoire des colonies françaises ( $1^{\mathrm{er}}$ trimestre 1914): 112.

(14.) Masonnen, Negroland Revisited, 465.

(15.) Dulucq, Écrire l'histoire, 98.

Page 21 of 25

PRINTED FROM the OXFORD RESEARCH ENCYCLOPEDIA, AFRICAN HISTORY (oxfordre.com/africanhistory). (c) Oxford University Press USA, 2018. All Rights Reserved. Personal use only; commercial use is strictly prohibited (for details see Privacy Policy and Legal Notice). 
(16.) Johannès Tramond, "Note bibliographique sur les archives du sultan Ahmadou," Revue de l'Histoire des Colonies françaises ( $4^{\mathrm{e}}$ trimestre 1924): 608-611.

(17.) Dulucq, Écrire l’histoire, 52-53.

(18.) Conklin, "What Is Colonial Science?”

(19.) Singaravélou, Professer l'empire, 35.

(20.) For further details, see Dulucq, Écrire l'histoire, 66-69.

(21.) Dulucq, 70.

(22.) François Pouillon, "Du savoir malgré tout: La connaissance coloniale de l'extrêmesud tunisien," in Connaissances du Maghreb: Sciences sociales et colonisation, ed. JeanClaude Vatin (Paris: Centre National de la Recherche Scientifique, 1984), 79-94.

(23.) Conklin, "What Is Colonial Science?”

(24.) Marcel Dubois and Auguste Terrier, Les colonies françaises, vol. 1: Un siècle d'expansion coloniale (Paris: Augustin Challamel, 1901), 1031.

(25.) Dulucq, Écrire l'histoire, 122.

(26.) Prosper Cultru, Un empereur de Madagascar au xviiie siècle: Benyowszky (Paris: Augustin Challamel, 1906).

(27.) Georges Hardy, Vue générale de l'histoire d'Afrique (Paris: Armand Colin, 1922), 1314.

(28.) Hardy, 64.

(29.) Edith Sanders, "The Hamitic Hypothesis: Its Origins and Functions in Time Perspective," Journal of African History 10 (1969): 513-532.

(30.) Conklin, "What Is Colonial Science?"

(31.) Emmanuelle Sibeud, Une science impériale pour l'Afrique? La construction des savoirs africanistes en France, 1878-1930 (Paris: Éditions de l’École des Hautes Etudes en Sciences Sociales, 2002), 85.

(32.) Augustin Holl, "West African Archaelogy: Colonialism and Nationalism," in A History of African Archeology, ed. Peter Robertshaw (London: James Currey, 1990), 299.

(33.) Raymond Mauny, Les siècles obscurs de l'Afrique noire (Paris: Fayard, 1970), 6.

(34.) Jean-Louis Triaud, "Haut-Sénégal Niger, un modèle positiviste? De la coutume à l'histoire: Maurice Delafosse et l'invention de l'histoire africaine," in Maurice Delafosse: 
Entre orientalisme et ethnographie, ed. Jean-Loup Amselle and Emmanuelle Sibeud (Paris: Maisonneuve et Larose, 1998), 210.

(35.) Masonnen, Negroland Revisited, 506.

(36.) Dulucq, Écrire l'histoire, 111-112.

(37.) About the relationships between Monteil, Tamura Koré and Garan Kuyaté: see Charles Monteil, Les Bambaras du Segou et du Kaarta: Étude historique, ethnographique et littéraire d'une peuplade du Soudan français (Paris: Émile Larose, 1924); about Gaden and Kamara, see Anna Pondopoulo, "Une histoire aux multiples visages: La reconstruction coloniale de l'histoire du Fuuta sénégalais au début du $\mathrm{XX}^{\mathrm{e}}$ siècle," Outre-mers, Revue d'histoire ( $2^{\mathrm{e}}$ semestre 2006): 57-78; about Delafosse, Hardy, Travélé, Kane, and Diagne: see Anne Piriou, "Intellectuels colonisés et écriture de l'histoire en Afrique de l'Ouest (c. 1920-c. 1945)," in Décoloniser l'histoire? De l'histoire coloniale aux histoires nationales en Afrique et en Amérique latine (xix ${ }^{e}-x x^{e}$ siècles), ed. Sophie Dulucq and Colette Zytnicki (Paris: Publications de la Société Française d'Histoire d'Outre-Mer, 2003), 69.

(38.) Jean Boulègue, “À la naissance de l’histoire écrite sénégalaise: Yoro Dyao et ses modèles ( $2^{\mathrm{e}}$ moitié du xix ${ }^{\mathrm{e}}$ siècle - début du xx ${ }^{\mathrm{e}}$ siècle)," History in Africa 15 (1988): 395405.

(39.) David Robinson, “Un historien et anthropologue sénégalais: Shaikh Musa Kamara,” Cahiers d'Études africaines 109 (1988): 89-116; Dulucq, Écrire l'histoire, 172-173; Céline Labrune Badiane and Étienne Smith, Les hussards noirs de la colonie. Instituteurs africains et petites patries en AOF (Paris: Karthala, 2018): passim.

(40.) Maximilien Quenum, Au pays des Fons: Us et coutumes du Dahomey (Paris: Maisonneuve and Larose, 1936).

(41.) Paul Zachernuk, "African History and Imperial Culture in Colonial Nigerian Schools," Africa 68, no. 4 (1998): 484-507.

(42.) Sophie Dulucq and Colette Zytnicki, eds., "Savoirs autochtones et écriture de l'histoire en situation coloniale ( $\mathrm{xix}^{\mathrm{e}}-\mathrm{xx}^{\mathrm{e}}$ siècles): 'Informateurs indigènes,' érudits et lettrés en Afrique," special issue, Outre-Mers: Revue d’histoire 352-353 (2 ${ }^{\mathrm{e}}$ semestre 2006): 7-106.

(43.) Michael Doormont, "The Roots of Yoruba Historiography: Classicism, Traditionalism and Pragmatism," in African Historiography: Essays in the Honour of Jacob Ade Ajayi, ed. Toyin Falola (London: Longman, 1993), 57.

(44.) Dulucq, Écrire l'histoire, 227.

(45.) Dulucq, 246. 
(46.) François-Xavier Fauvelle, L'Afrique de Cheikh Anta Diop: Histoire et idéologie (Paris: Karthala, 1996).

(47.) Abdoulaye Ly, La Compagnie du Sénégal de 1673 à 1696: L'évolutiondu commerce français d'Afrique Noire dans le dernier quart du xviie siècle (Paris: Présence Africaine, 1958).

(48.) Sylvie Kandé, "L'établissement d'un empire (du savoir) colonial: Compte rendu de lecture de Jean-Loup Amselle et Emmanuelle Sibeud (éd.), Maurice Delafosse: Entre orientalisme et ethnographie, l'itinéraire d'un africaniste (1870-1926)," Cahiers d'Études Africaines no. 57 (2000): 157.

(49.) Masonnen, Negroland Revisited.

(50.) John Fage, "History," in The African World. A Survey of Social Research, ed. R. A. Lystad (London: Pall Mall, 1965), 41.

(51.) A. F. Afigbo, “Colonial Historiography," in African Historiography: Essays in the Honour of Jacob Ade Ajayi, ed. Toyin Falola (London: Longman, 1993), 39.

(52.) Jewsiewicki and Newbury, African Historiographies.

(53.) Pierre Bourdieu, "Les conditions sociales de la production sociologique: Sociologie coloniale et décolonisation de la sociologie," in Moniot, Le Mal de voir, 419.

(54.) Moniot, Le Mal de voir; Philippe Lucas and Jean-Claude Vatin, eds., L'Algérie des anthropologues (Paris: Maspero, 1982); Gérard Leclerc, Anthropologie et colonialism: Essai sur l'histoire de l'africanisme (Paris: Fayard, 1972); and Daniel Nordman and JeanPierre Raison, eds., Sciences de l'Homme et conquête coloniale: Construction et usages des sciences humaines en Afrique, $\chi_{i x}{ }^{e}-\chi^{e}$ siècles (Paris: Presses de l'École Normale Supérieure, 1980).

(55.) Moniot, Le mal de voir.

(56.) Véronique Dimier, "La "science" coloniale en Angleterre et en France. Une arme dans les relations internationales," in Les sciences de gouvernement, ed. Olivier Ihl, Martine Kaluszynski, and Pollet, Gilles (Paris: Economica, 2003), 69-85; Pierre Singaravélou, ed., L'empire des géographes: Géographie, exploration et colonisation, xix ${ }_{-}$ $x x^{e}$ siècle (Paris: Belin, 2008); Singaravélou, Professer l'empire; Hélène Blais, Mirages de la carte: L'invention de l'Algérie coloniale (Paris: Fayard, 2014); and Hélène Blais, Florence Deprest, and Pierre Singaravélou, "French Geography, Cartography and Colonialism," Journal of Historical Geography 37 (2011): 146-148.

(57.) Piriou and Sibeud, L'africanisme en questions; and Sibeud, Une science impériale.

(58.) See note 6 for Conklin's remarks on Tilley's book.

Page 24 of 25

PRINTED FROM the OXFORD RESEARCH ENCYCLOPEDIA, AFRICAN HISTORY (oxfordre.com/africanhistory). (c) Oxford University Press USA, 2018. All Rights Reserved. Personal use only; commercial use is strictly prohibited (for details see Privacy Policy and Legal Notice). 
(59.) Henri Brunschwig, "French Historiography since 1945 concerning Black Africa," in Reappraisals in Overseas History: Essays on Post-War Historiography about European Expansion, ed. Peter Emmer and Henri Wesseling (Leiden, the Netherlands: Leiden University Press, 1979), 84-97; Bathily, "Aux origines de l'africanisme"; Monique Lakroum, “De l'histoire coloniale à l'histoire africaine (1912-1960), in L'Afrique occidentale au temps des Français: Colonisateurs et colonisés (1860-1960), ed. Catherine Coquery-Vidrovitch and Odile Goerg (Paris: La Découverte, 1992), 37-47; and Dulucq, Écrire l'histoire.

(60.) For instance, the Bulletin des travaux historiques et scientifiques de l'Afrique occidentale française; and the Bulletin de la Société des recherches congolaises.

\section{Sophie Dulucq}

Department of History, University of Toulouse - Jean Jaurès

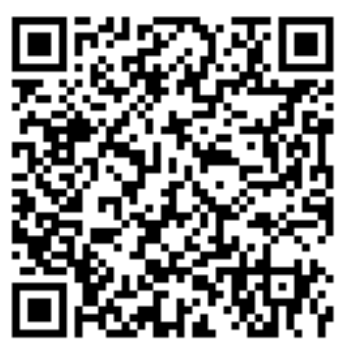

